\title{
Pharmacognostical and Phytochemical Analysis on Leaves of Homalium ceylanicum (Gardn.) Benth.
}

\author{
Acharya Rabinarayan*1, Jani Switu², Chinappa Rudrappa ${ }^{3}$, Shukla Vinay ${ }^{4}$
}

\section{Acharya Rabinarayan*1, Jani Switu², Chinappa Ru- drappa $^{3}$, Shukla Vinay ${ }^{4}$}

'Head of Dravyaguna department, Room no. 329, $3^{\text {rd }}$ floor, New Building, IPGT and RA, Gujarat Ayurved University, Jamnagar, INDIA.

${ }^{2}$ Senior Research fellow, Dravyguna department, IPGT and RA, GAU,

Jamnagar, INDIA.

${ }^{3} \mathrm{C} R$ Harisha-co investigator, Head Pharmacognosy lab, IPGT and RA, GAU, Jamnagar, INDIA.

${ }^{4}$ Shukla Vinay-co investigator, Head Pharmaceutical chemistry lab, IPGT and $R A$, GAU, Jamnagar, INDIA.

\section{Correspondence}

\section{Acharya Rabinarayan}

Head of Dravyaguna department, Room no. 329, 3rd floor, New Building, IPGT andRA, Gujarat Ayurved University, Jamnagar- 361008, INDIA.

Phone No: + 9924585855

E mail Id: drrnacharya@gmail.com

\section{History}

- Submission Date: 25-11-2017;

- Review completed: 18-12-2017;

- Accepted Date: 27-12-2017

\section{DOI : 10.5530/pj.2018.2.48}

\section{Article Available online}

http://www.phcogj.com/v10/i2

\section{Copyright}

(C) 2018 Phcog.Net. This is an openaccess article distributed under the terms of the Creative Commons Attribution 4.0 International license.

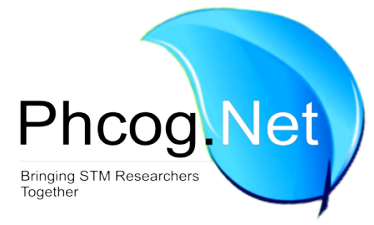

\begin{abstract}
Objective: Kakhara, Dhanimari or Kakhda is one of the folklore plant of Odisha, which has been identified as Homalium ceylanicum (Gardn.) Benth. (Syn. H. zeylanicum) belonging to family Salicaceae (Flacourtiaceae). The leaves and bark of the plant is used in rheumatism, diabetes and wound healing. Review of literature revealed that the scientific evaluation on various parts of the plants has not been carried out, hence the present study has been designed to study leaves of Homalium ceylanicum Benth. For its morphology, anatomy, physiochemical and phytochemical aspects. Methods: The leaves samples were collected from Gandhamardana hills, Odisha, in month of September 2016, herbarium was provided with herbarium reference no. phm/6216/2016-17 and also certified by BSI Kolkata. Macroscopic observations were made with naked eyes and centimeter scale was used to measure the leaf size. Microscopy of leaf, Stomatal index and powder microscopy was done as per standard protocol. Physicochemical and qualitative analysis were done following standard API protocols. Results: Leaves are simple, alternate, with crenate margin and petiole is pubescent. T.S. of petiole shows boat shaped with two protruding arms supported by 2 meristele. The schematic diagram of T.S. of petiole shows somewhat orbicular to boat shaped with two arms protruding supporting two meristele in each arm. Stomatal index is 15.94-16.91, powder is bitter with leafy aroma, microscopic shows paracyctic stomata key character of genus. LOD is $8.66 \pm 0.72$ and carbohydrates are present in both extracts. Conclusion: The anatomical characters and values obtained from analytical study can help in standardization.

Key words: Anukta Dravya, Flacourtiaceae, Homalium ceylanicum, Leaf, Salicaceae.
\end{abstract}

\section{INTRODUCTION}

India has one of the richest plant based traditional medicine in the world which are well documented in certain classical texts. Some of the plants are use traditionally, which are not a part of classical texts of Ayurveda or pharmacopoeia and are enumerated into the category of ethano medicinal plants or extra pharmacopeial plants (Anukta Dravya). ${ }^{1}$

Kakhara, Dhanimari or Kakhda. ${ }^{2}$ is one of the folklore plant of Odisha, stem bark is used in the management of fever and its leaves mixed with jhuna dust (Shorea robusta oleo gum resin) acts as mosquito repellent. ${ }^{3}$ The leaves and bark of the plant is used in rheumatism, diabetes and wound healing. ${ }^{4}$

Botanically Kakhara has been identified as Homalium ceylanicum (Gardn.) Benth. (Syn. H. zeylanicum). ${ }^{5}$ It belongs to family Salicaceae (Flacourtiaceae). ${ }^{6}$

Homalium ceylanicum is a large evergreen tree, with alternate crenate leaves bearing petiole and raceme inflorescence. ${ }^{7}$ Review of literature revealed that the scientific evaluation on various parts of the plants, to establish its Pharmacognostical characters, has not been carried out. Hence the present study has been designed to study Homalium ceylanicum Benth. leaves for its morphology, anatomy, physiochemical parameters and phytochemical screening including HPTLC.

\section{MATERIALS AND METHODS}

\section{Collection and authentication}

The leaves samples were collected by the SRFfrom one of its natural habitat, Gandhamardana hills, Odisha, in month of September 2016 with help of local taxonomist. Herbarium was submitted to pharmacognosy laboratory authentified by the Pharmacognosist of the institute and provided with herbarium reference no. phm/6216/2016-17 and also certified by BSI Kolkata with letter no. $\mathrm{CNH} / 55 \mathrm{~b} / 2013 /$ Tech. II/116. (Figure 1)

\section{Pharmacognostical study}

Macroscopic observations were made with naked eyes and centimeter scale was used to measure the leaf size. The leaves were washed and transverse sections were taken cleared with choral hydrate to observe the anatomy of leaf with help of Quasmo binocular compound microscope. For histochemical test the thick Transverse sections of the leaves were exposed to Idoine, Phloroglucinol and $\mathrm{HCl}$ for observation of starch grain and lignified tissue.

For surface study, triplicate reading were taken for trichomes, stomata length width and stomatal index was calculated taking into consideration six consecutive readings along with Standard Deviation. 


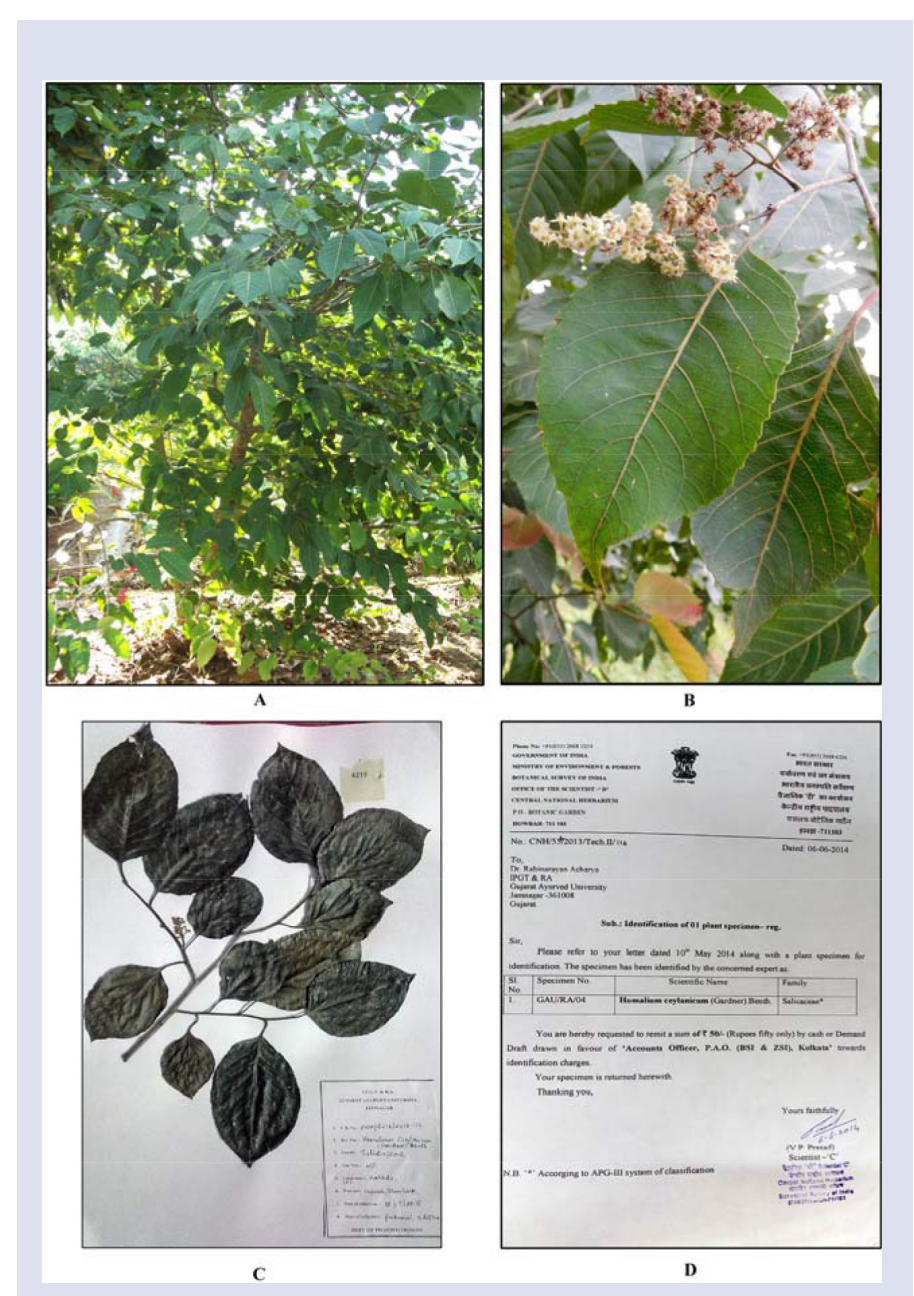

Figure 1A: Plant in Natural Habitat, B: Flowering Twig of the tree, C: Herbarium phm/6216/2016-17, D: Certificate from BSI.

For powder microscopy, to obtain powder shaded dried leaves were grounded by mechanical grinder and sieved through $80 \#$. For micrometry, triplicate reading were recorded and mean value was taken into consideration along with standard mean of deviation. ${ }^{8}$

\section{Physicochemical parameters and qualitative analysis}

The leave powder was exposed to Physico-chemical i.e. $\mathrm{pH}$, loss on drying, total ash value, acid insoluble ash value, water soluble extractive value and alcohol soluble extractive value, protocols followed as recommended by API. For qualitative analysis, the presence of various secondary metabolites dissolved in water and alcohol extract was done as per reference. ${ }^{9,10}$

\section{HPTLC Study}

Methonalic extract of leaves were exposed to HPTLC study. The solvent system used for the study is toluene: ethyl acetate (9:1)

\section{Chromatographic conditions}

$\begin{array}{lll}\text { Application mode } & : & \text { Camag Linomat V } \\ \text { Development Chamber } & : & \text { Camag Twin trough Chamber. } \\ \text { Plates } & : & \text { Precoated Silica Gel } \\ \text { Cha254 } & \text { Plates. } \\ \text { Development Time } & : & 30 \mathrm{~min} .\end{array}$
Scanner
Detection
Camag Scanner III.
Data System
Deuterium lamp, Tungstan Lamp
Win cats software.

\section{Spray reagent ${ }^{11}$}

Preparation: $0.5 \mathrm{~g}$ Vanillin is dissolved in $100 \mathrm{ml}$ sulphuric acid-ethanol $(40+10)$. Or $1 \mathrm{~g}$ of Vanillin was dissolved in $100 \mathrm{ml} \mathrm{conc}$. Sulphuric acid. Treatment after spraying: heated at $120^{\circ} \mathrm{C}$ until maximum spot colour intensity was reached.

\section{RESULTS}

\section{Macroscopic study}

Leaves are simple, measures about 8.3-15 × 4.7-9 cm, alternate, stipulate, petiolate, ovate to oblong, crenate, acuminate apex, glabrous, dark green above, parrot green beneath and having reticulate venation. 6-10 pairs of main nerves arising from mid rib, appearing yellowish green in colour on upper surface of leaf. Petiole measure about $1.2-1.5 \mathrm{~cm}$ in length and is covered with minute hairs. (Figure 2, A)

\section{Miscroscopic study T.S. of petiole}

The schematic diagram of T.S. of petiole shows somewhat orbicular to boat shaped with two arms protruding supporting two meristele in each arm measuring about $0.36 \mu \mathrm{m} \times 0.50 \mu \mathrm{m}$ near arm $(4 \times)$. (Figure $2, B$ )

Detailed T.S. of petiole shows single layered epidermis interrupted by unicellular covering trichome, along with thick layer of cuticle, 1-2 layer of hypodermis followed by parenchyma cells filled with chlorophyll pigments forming 5-9 layers of cortical cells, some cells are embedded with rosette crystals, rarely prismatic crystals of calcium oxalate and red colored pigments. Some of the cortical cells are pitted and lignified. Single layered endodermis continuous all over the ground tissue. 2-3 layered thick lignified pericylic fibres running all around the ground tissue just beneath the endodermis. Rectangular and diamond shaped prismatic crystal present adjacent to the pericylic fiber. Vascular bundle consist of phloem towards cortex made up of fibers and sieve elements, xylem radially arranged. Protoxylem towards pith and metaxylem towards phloem made up of xylem fibers and parenchyma. Reduced pith is occupying the center of the section, cells often filled with rosette and cluster crystals. Two identical vascular bundle representing meristele at the corner of the two arms. (Figure 2, C-H)

\section{T.S. of leaf passing through Midrib}

The schematic diagram of T.S. of leaf passing through midrib shows bulged center with lamina extension in the same line. The midrib region measures about $0.25 \mu \mathrm{m}$ in diameter and lamina region measures about $0.09 \mu \mathrm{m}$ in diameter $(4 \times)$. (Figure 3, A)

Detail T.S. passing through mid-rib shows two layered upper and lower epidermis with thick layer of cuticle, which slowly merges into single layer epidermis in extended arms of lamina. Some of the lower epidermal cells are thick and lignified often interrupted by stomatal openings and simple unicellular trichome. Beneath the epidermis 1-2 layers of compactly arranged collenchyma cell, some of the collenchymatous cells shows lignfication, parenchymatous cells forming 4-8 layered ground tissue often filled with cluster and rosette crystals. Single layered bundle sheath encircled by 2- 3 layers of pericylic fibers followed by several layers of parenchyma cells embedded with rosette, cluster and few prismatic crystals of calcium oxalate. Centrally located main vascular bundle radially arranged with continuous ring of xylem. Xylem made up of xylem parenchyma and it is fibers. Phloem is situated at the base of xylem and towards lower epidermis. Two meristele represents the vascular 


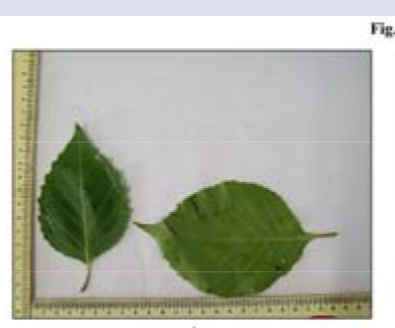

$\mathbf{A}$
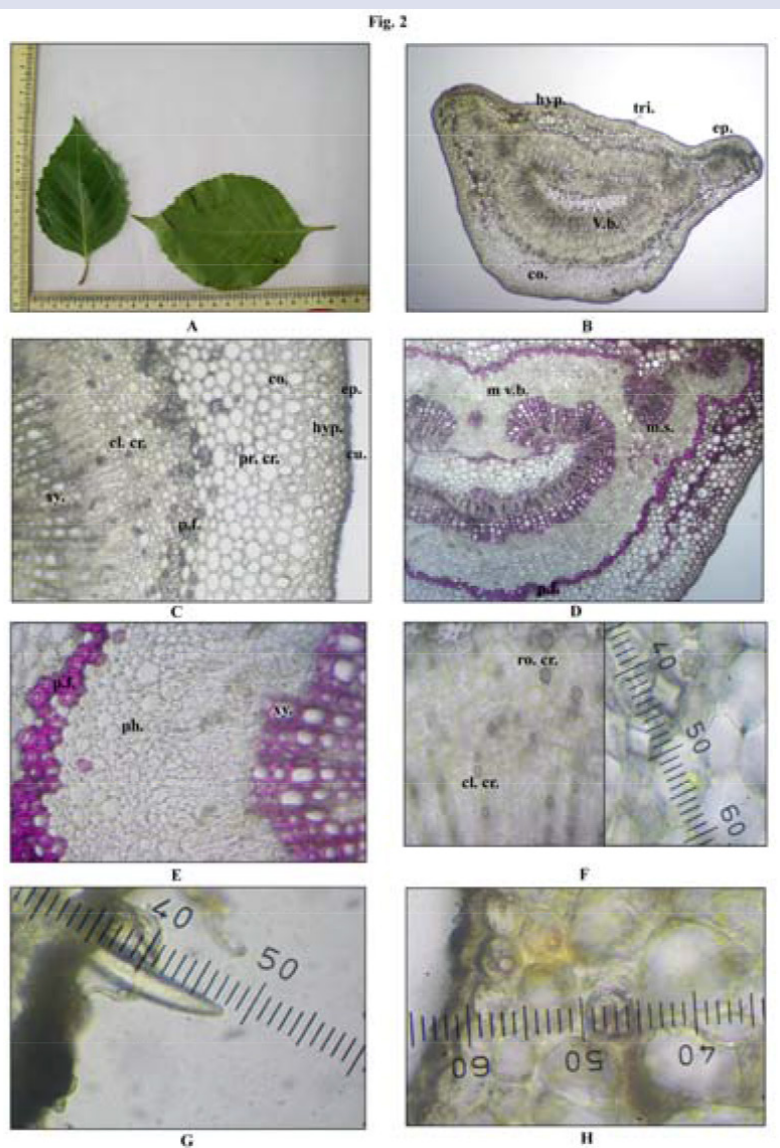

Figure 2A: leaf and petiole measurement, B: T.S. of Petiole, C: Detailed T.S. of Petiole, D: T.S. of Petiole (stained), E: enlarge view of vascular bundle, F: cluster, rossete and diamond shaped crystals, G: micro measurement of simple trichome, $\mathrm{H}$ : micro measurement of rostte crystal tri. - trichome, hyp.- Hypodermis, ep. - Epidermis, v.b. - vascular bundle, co. - cortex, cu. - cuticle, p.f. - pericyclic fiber, cl.cr. - cluster crystal, xy. - Xylem, m.v.b. - main vascular bundle, m.s. -meristele, ph. - phloem, ro.cr. Rosette crystal.

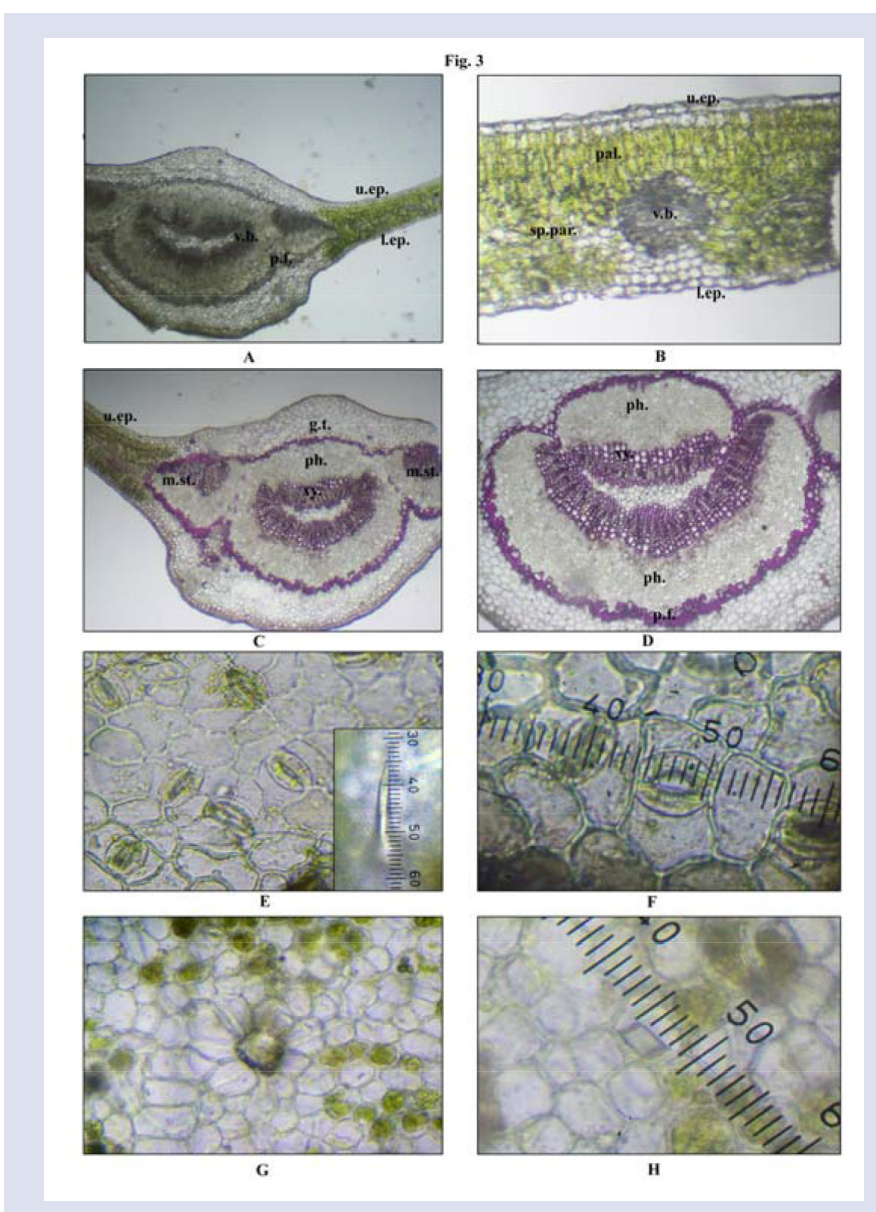

Figure 3 A:T.S. of leaf passing through mid rib, B:T.S. of Lamina, C:T.S. of leaf passing through mid-rib (Stained), D: Enlarged view of main vascular bundle, E: Paracytic stomata micro measurement of trichome, F: Micro measurement of stomata (lower surface), G: Cicatrix present in upper epidermis surface, $\mathrm{H}$ : Micro measurement of rectangular crystal u.ep. - upper epidermis, l.ep. - Lower epidermis, sp. par. - Spongy parenchyma, m.st. - Meristele, g.t. - ground tissue.

of calcium oxalate and cicatrix are found in surface of upper epidermis of leaf. (Figure 3, E-H)

\section{Powder microscopy}

Powder was green in colour with leafy smell, fine texture and bitter astringent taste. Diagnostic powder characters observe under microscope are simple unicellular trichome, prismatic crystals, rhomboidal crystals, fragment of paracytic stomata, fragment of upper epidermal cell in surface view, diamond shaped prismatic crystals and fragment of spiral and pitted vessels. (Figure 4, A-B)

Trichome $2.16( \pm 0.55) \times 0.4 \mu \mathrm{m}$, prismatic crystals $0.4 \times 0.5 \mu \mathrm{m}$, rhomboidal crystal $0.4 \times 0.3 \mu \mathrm{m}$, fragment of stomata $0.5 \times 0.3 \mu \mathrm{m}$, diamond shaped crystal $0.8 \times 0.6 \mu \mathrm{m}$. (Figure $4 \mathrm{C}-\mathrm{L}$ ).

\section{Physicochemical parameters}

The $\mathrm{pH}$ of leaf water extract was found to be 5.02 at $31.1^{\circ} \mathrm{C}$, other values are described in Table 1 along with calculated deviation. 

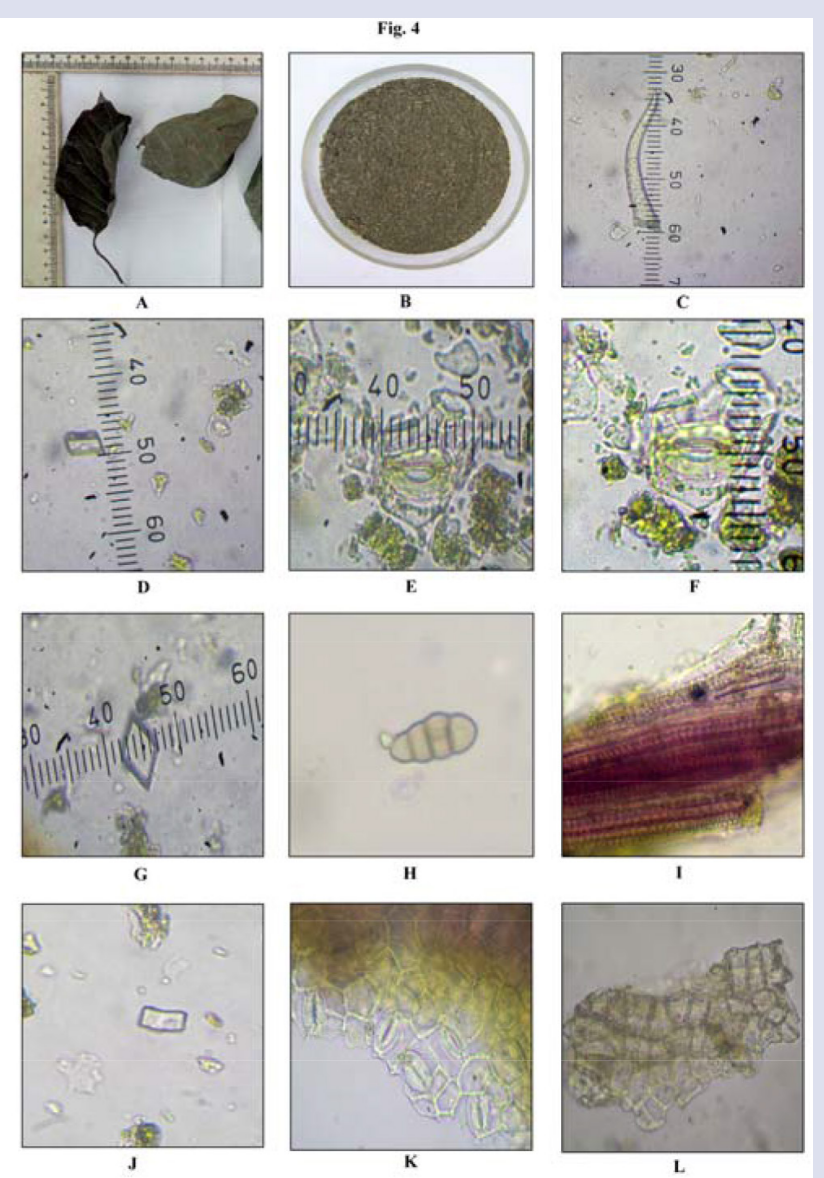

Figure 4 A: Dry leaves, B: Dried leaf powder, C: Simple warty trichome, D: Micro measurement prismatic crytals, E: Micro measurement stomata (length), F: Micro measurement stomata (width), G: Micro measurement of prismatic crystal, H: Pleuricellular trichome, I: lignified group of vessels, J: Rhomboidal crystal, K: Fragment of lower epidermis, stomata (surface view), L: Fragment of upper epidermis (suface view).

Table 1: Physicochemical parameters of Homalium ceylanicum (Gardn.) Benth. Leaves.

\begin{tabular}{cc}
\hline Parameters & Results $(\% \mathrm{~W} / \mathrm{W})$ \\
\hline Loss on drying & $8.66 \pm 0.72$ \\
Total Ash value & $7.83 \pm 0.19$ \\
Acid insoluble ash value & $1.15 \pm 0.07$ \\
Water extractive value & $19.80 \pm 1.98$ \\
Alcohol extractive value & $11.17 \pm 0.88$ \\
\hline
\end{tabular}

\section{Qualitative study}

Qualitative analysis on water and alcohol soluble extracts shows presence of carbohydrate, alkaloid and tannin. Results of other tests conducted are mentioned in Table 2. Carbohydrate and phenolic compounds are present in water and alcoholic extract of leaf, while alkaloid is found to be present only in alcoholic extract of leaf.

\section{HPTLC Study}

The methanol extract of leaf shows 6 peaks, 5 peaks and 6 peaks at UV Vis range of $254 \mathrm{~nm}, 366 \mathrm{~nm}$ and $600 \mathrm{~nm}$ respectively. After spraying with

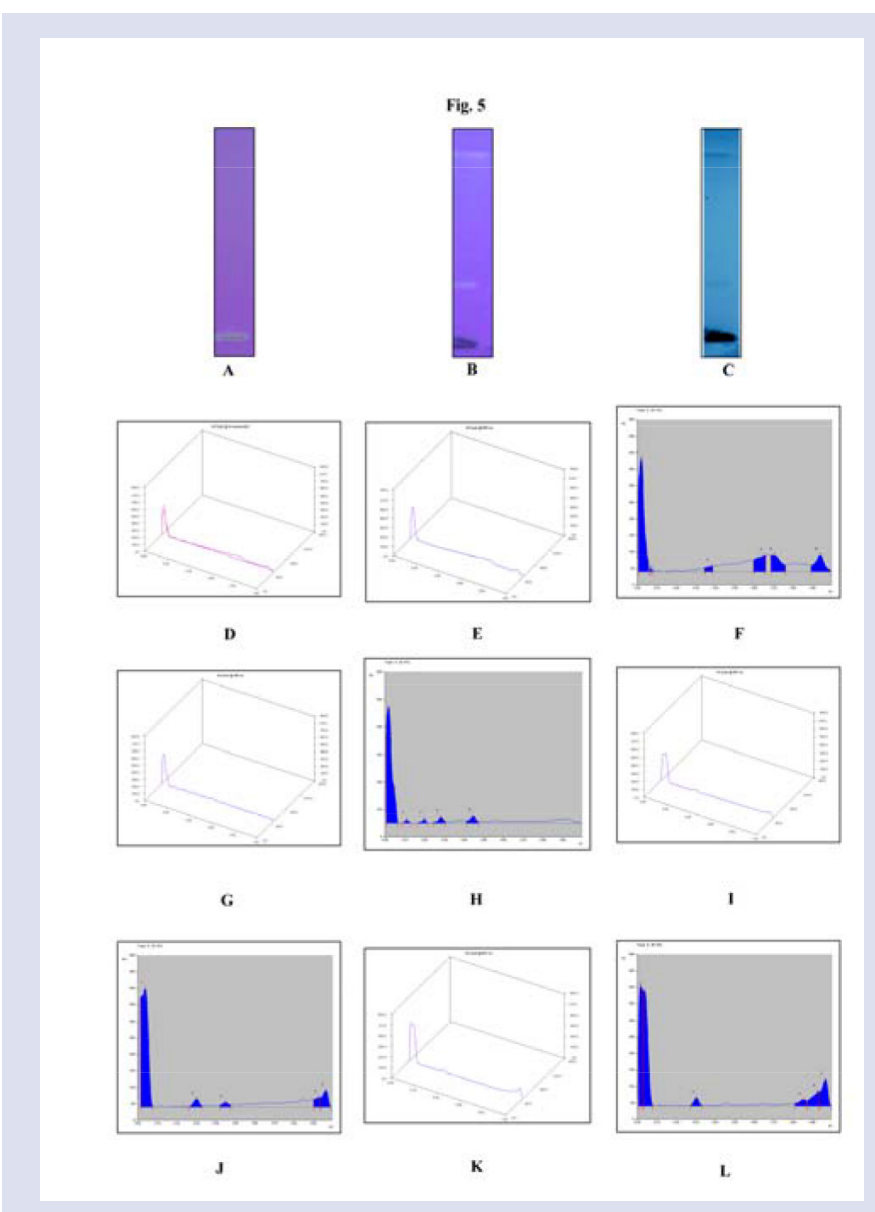

Figure 5 A: HPTLC plate before spray at $366 \mathrm{~nm}, \mathrm{~B}$ : HPTLC plate after spray at $366 \mathrm{~nm}, \mathrm{C}:$ HPTLC plate after spray in visible light, D: $3 \mathrm{~d}$ graph at uv vis range, E: all tracks $3 \mathrm{~d}$ graph at $254 \mathrm{~nm}, \mathrm{~F}:$ Peak display at 254 $\mathrm{nm}, \mathrm{G}: 3 \mathrm{~d}$ graph at $366 \mathrm{~nm}, \mathrm{H}$ : peak display at $366 \mathrm{~nm}, \mathrm{l}: 3 \mathrm{~d}$ graph at $366 \mathrm{~nm}$ after spray, J: peak display after spray at $366 \mathrm{~nm}, \mathrm{~K}: 3 \mathrm{~d}$ graph at $600 \mathrm{~nm}$, L: peak display at $600 \mathrm{~nm}$.

spray reagent 5 peaks are obtained at $366 \mathrm{~nm}$. The $\mathrm{R}_{\mathrm{f}}$ values are presented in the Table 3 and the photographs along with peak display are shown in Figure 5.

\section{DISCUSSION}

Leaves are simple, alternate with crenate, acuminate tip and glabrous which are key characters for identification of Family Flacourtiaceae. ${ }^{7}$

T.S. of petiole shows presence of unicellular trichomes and one main vascular bundle with three meristele which are becoming united to form an arc on the adaxial side are typical characters of Flacourtiaceae, leaf petiole's anatomy. T.S. of leaf shows simple unicellular trichome, cuticle showing split markings and presence of cluster crystals are special character of Homalium genus. Surface study shows paracytic type of stomata. Absence of stomata on upper surface are identifying characters of Homalium genus. ${ }^{12}$ Moreover, the stomatal index marks as one of the main identification parameter for standardization. Micro-measurement of paracytic stomata in powder microscopic study can help in identification of the plant even in powder form. Values obtained from analytical study can be useful in identification and further in preparation of monograph. Carbohydrate and phenolic compounds are present in both extracts supporting the reference. ${ }^{13}$ The chromatographic profile 
Table 2: Results of Qualitative analysis Homalium ceylanicum (Gardn.) Benth. Leaves.

\begin{tabular}{ccc}
\hline Tests & Water extract & Alcohol extract \\
\hline Molisch's test & ++ & ++ \\
Fehling test & ++ & ++ \\
Dragendroff test & -- & ++ \\
Haggers test & -- & -- \\
Wagner's test & -- & -- \\
Biuret & -- & -- \\
Ninhydrin test & -- & -- \\
Bountrager's test & -- & -- \\
Neu. Ferric chloride & ++ & ++ \\
Lead acetate & ++ & ++ \\
Copper sulphate & -- & ++ \\
Seliwenoff's test & -- & -- \\
Salkowski test & -- & -- \\
Shinoda test & -- & -- \\
Vanillin + sulphuric acid & -- & -- \\
\hline
\end{tabular}

Table 3: Rf values obtained at UV and visible range of $\boldsymbol{H}$. ceylanicum (Gardn.) Benth. Leaves.

\begin{tabular}{cccc}
\hline$R_{\mathrm{f}}$ at 254 nm & $R_{\mathrm{f}}$ at $366 \mathrm{~nm}$ & After spray (366 nm) & $\begin{array}{c}\text { Visible }(600 \\
\mathrm{nm})\end{array}$ \\
\hline 0.02 & 0.02 & 0.04 & 0.02 \\
0.07 & 0.11 & 0.30 & 0.04 \\
0.38 & 0.20 & 0.45 & 0.30 \\
0.65 & 0.28 & 0.93 & 0.85 \\
0.70 & 0.45 & 0.97 & 0.93 \\
0.94 & - & - & 0.97 \\
\hline
\end{tabular}

obtained for Methanolic extract of leaf can be helpful for further standardization of plant.

\section{CONCLUSION}

The macroscopic characters like simple leaf, crenate margin, pubescent petiole and microscopic characters like presence of unicellular trichome, main vascular bundle uniting with three meristele forming an arc is observed in T.S. of petiole, cuticle showing split marking and presence of cluster crystals in T.S. of leaf are identifying character of Homalium ceylanicum Benth. Presence of paracyctic stomata in lower surface and absence of it in upper surface, stomatal index 15.94-16.91 are the key characters of Homalium ceylanicum Benth. The observed physicochemical, qualitative test and HPTLC results will help in further standardization of the plant.

\section{ACKNOWLEDGMENT}

We would like to thank Ministry of AYUSH, Government of India, and Director of IPGT and RA, Gujarat Ayurved University for funding the project and all the supporting laboratory heads and staff members of IPGT and RA.

\section{ABBREVIATIONS USED}

T.S: Transverse section; cm: centimeter; g: gram/s; w/w: weight by weight; nm: nanometer; HPTLC: high performance thin layer chromatography; Rf: retardation factor.

\section{CONFLICT OF INTEREST}

The authors declare no conflict of interest.

\section{REFERENCES}

1. Retnam KR, Martin P. Ethnomeidicinal Plants. Jodhpur: Agrobios.2008, p.1.

2. Brahmam M, Saxena HO, Flora of Orissa. Vol I.; Orissa: Regional Research laboratory.1994. p. 522.

3. Pattanayak B. Dhal NK. Plants having mosquito repellent activity: an ethnobotanical survey. Int. J. Res. Dev. Pharm. L. Sci. 2015;4(4):1760-5.

4. Prasad SK. et al. Assessment of analgesic and anti-inflammatory effect of Homalium zeylanicum. JGTPS. 2014;5(3):1886-90.

5. International plant name index [homepage on internet]. 2004. Available from: http://www.ipni.org/ipni/idplantnamesearcg.do.

6. Sue Zmarzty Don Krikup, herbarium, Kew. Interactive Key to Genera of Salicaceae sensu lato and Achariaceae sensu lato. www.kew.org/herbarium/ keys/flacs/_baks/index.html.0006.d323.bak.

7. Gamble JS. Flora of the presidency of madras. Vol. I.; Dehradun: Bishen singh, manhendra pal singh. 1967. p. 522.

8. Trease Evans. Pharmacognosy. 16th ed. London: Saunders Elsevier. 2009;567-68.

9. Anonymous. The Ayurvedic Pharmacopoeia of India. Part- II, Vol-II, 1st Ed. New Delhi: Government of India, Ministry of Health and Family Welfare, Department of AYUSH. 2008.

10. Khandelwal KR. Practical Pharmacognosy. 19th ed. Pune: Nirali Prakashan; 2008.

11. Egon S. Thin Layer Chromatography. Springer Publication. 1969, reprint 2005.

12. Metcalfe CR and Chalk L. Anatomy of the dicotyledons. Vol-I, Great Britain: Oxford university press. 1950;116-119

13. Rastogi RP, Mehrotra BN. Compendium of Indian medicinal plants. Vol-5, New Delhi: Central Drug Research Institute.1990;174-8.

\section{SUMMARY}

- Kakhara, Dhanimari or Kakhda is one of the folklore plant of Odisha, which has been identified as Homalium ceylanicum (Gardn.) Benth. (Syn. H. zeylanicum) belonging to family Salicaceae (Flacourtiaceae). The leaves and bark of the plant is used in rheumatism, diabetes and wound healing. The present study has been designed to study leaves of Homalium ceylanicum Benth. for its morphology, anatomy, physiochemical and phytochemical aspects. The leaves samples were collected from Gandhamardana hills, Odisha, in month of September 2016. The Leaves are simple, alternate, with crenate margin and petiole is pubescent. T.S. of petiole shows boat shaped with two protruding arms supported by 2 meristele. The schematic diagram of T.S. of petiole shows somewhat orbicular to boat shaped with two arms protruding supporting two meristele in each arm. Stomatal index is 15.94-16.91, powder is bitter with leafy aroma, microscopic shows paracyctic stomata key character of genus. LOD is $8.66 \pm 0.72$ and carbohydrates are present in both extracts. the anatomical characters and values obtained from analytical study can help in standardization. 
GRAPHICAL ABSTRACT

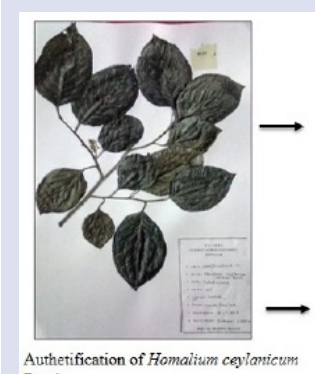
Benth.

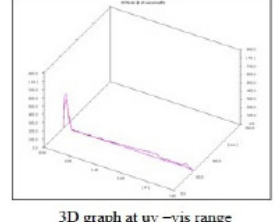

3D graph at uv -vis range
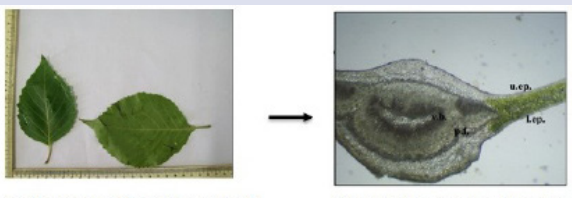

Fresh leaves of H. coylanicum Benth.

TS. of leaf passing through midrib

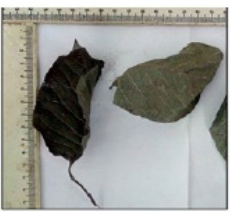

Dry leaves of $H$. ceylanicum Benth.
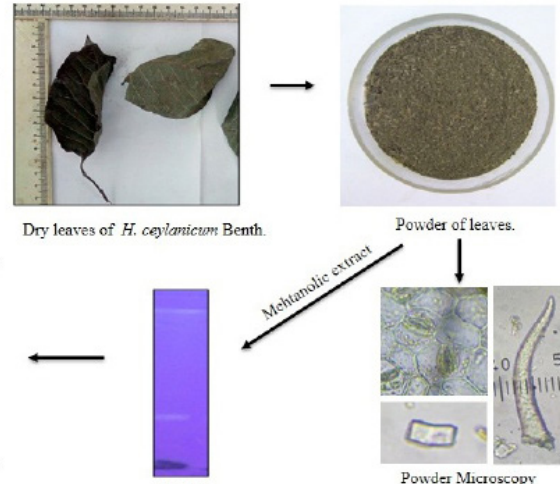

HPTLC
Powder of leaves.

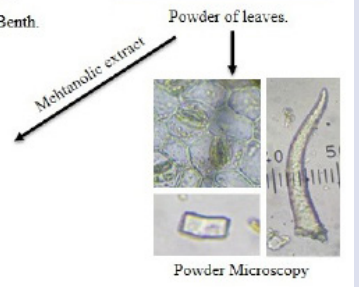

\section{ABOUT AUTHORS}

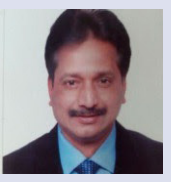

Rabinarayan Acharya: Born on $26^{\text {th }}$ February 1967, is working as a Professor and Head Dravyaguna, at Institute for Post Graduate Teaching \& Research in Ayurveda, Gujarat Ayurved University, Jamnagar, Gujarat. He obtained his B.Sc. (Botany, Hons.), BAMS (Hons.) degree from Utkal University, PG Diploma in Bio Ethics from IGNOU \& M.D. (Ayu.) (1996) and Ph.D.(2003) in Dravyaguna from Gujarat Ayurved University, Jamnagar. $\mathrm{He}$ has more than 21 years of research experience in the field of standardization of poisonous herbal drugs and extra-pharmacopoeial ayurvedic drugs of herbal origin.

Cite this article: Rabinarayan A, Switu J, Harisha CR, Vinay S. Pharmacognostical and Phytochemical Analysis on Leaves of Homalium ceylanicum (Gardn.) Benth. Pharmacog J. 2018;10(2):272-7. 